\title{
IgA serum levels and disease activity in ankylosing spondylitis: a prospective study
}

\author{
M J A M FRANSSEN. ' L B A VAN DE PUTTE.' AND F W J GRIBNAU ' \\ From the 'Divisions of Rheumatology and 'Clinical Pharmacology, University Hospital St Radboud, \\ Nijmegen, The Netherlands
}

SUMmary We investigated the possible association between serum $\operatorname{IgA}, \operatorname{IgM}$, and $\operatorname{IgG}$ anc $\mathscr{S}_{5}$ disease activity in a longitudinal study of 48 weeks' duration in 38 . male patients with actives

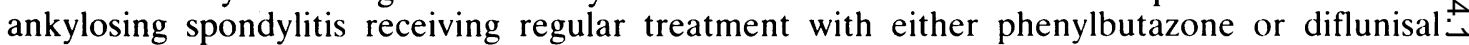
Throughout the study serum IgA levels correlated most frequently with chest expansion and lumbar flexion index, and patients with extensive radiological changes also had the highest serumb IgA levels. Likewise, changes in $\operatorname{IgA}$, but not in $\operatorname{IgM}$ and $\operatorname{IgG}$, correlated with changes in ig composite index of disease activity (IDA). Changes in erythrocyte sedimentation rate (ESR). showed a similar correlation with changes in IDA, whereas changes in serum IgA and ESR showed no consistent correlation, suggesting that both parameters reflect different aspects of disease. Serum IgA, ESR, and IDA values all decreased during regular drug treatment $\frac{3}{\sigma}$ suggesting a disease modifying effect of the non-steroidal anti-inflammatory drugs (NSAIDs) studied. Regular measurement of serum $\operatorname{IgA}$ may be useful in the assessment of disease activit $\overrightarrow{\mathrm{X}}$ of ankylosing spondylitis.

Two observations have recently pointed to the possible importance of serum IgA levels in ankylosing spondylitis (AS). Firstly, IgA serum levels have been found to be disproportionately raised compared with other immunoglobulins in $\mathrm{AS}^{1-4}$ Secondly, disease activity in AS has been associated with the presence of Klebsiella pneumoniae in the faeces of patients with $\mathrm{AS},,^{5-7}$ though other studies have been unable to confirm these data. ${ }^{8-10}$ Since humoral immune responses in the gut are mainly of the IgA type, ${ }^{11}$ several authors looked for and in fact found an association between serum IgA levels and disease activity in $\mathrm{AS}^{2312} 13$ If $\operatorname{IgA}$ serum levels are indeed a parameter for disease activity in AS, this would be helpful, because assessment of activity by clinical parameters is problematic in this disease, especially when peripheral arthritis is absent. Longitudinal studies on $\operatorname{IgA}$ serum levels and disease activity in AS have not so far been carried out.

The aim $o^{r}$ the present study was to investigate in a prospective, longitudinal way the possible rela-

Accepted for publication 22 April 1985.

Correspondence to Dr M J A M Franssen, University Hospital St Radboud, Geert Grooteplein Zuid 8, 6500 HB Nijmegen. The Netherlands. tionship between serum IgA levels and clinica disease activity in AS. This study was part of के clinical trial comparing the efficacy of two NSAIDs phenylbutazone and diflunisal, against disease activō ity in AS. In addition we studied possible correla tions between serum IgA levels and radiologica動 features of the disease.

\section{Patients and methods}

The present study was part of a clinical trial in male patients with ankylosing spondylitis, compas ing treatment with phenylbutazone and diflunisa $b$ Thirty eight patients were studied aged between $1 \frac{18}{8}$ and 55 years, with a diagnosis of ankylosing spond 8 litis according to the New York criteria ${ }^{14}$ confirmez: by two or more of the following symptoms: backs pain, morning stiffness, and progressive limitation off movement. Patients were admitted only when the showed a flare-up during or after a drug withdrawdip period of maximally 14 days. A flare-up was definee as a worsening of the patient's condition in whic pain and stiffness were essential components, re quiring treatment. After this wash-out period patients were randomly allocated to receive eithef diflunisal (500 mg twice daily) or phenylbutazont 
(200 $\mathrm{mg}$ twice daily), resulting in two treatment groups of 19 patients each. The study covered a 12-week double blind period followed by an open extension period up to week 48. Nine patients dropped out: three in each treatment group due to side effects and one in each group due to lack of efficacy. Another one was lost to follow up. Of the parameters studied the following are relevant to the present report: dominant spinal pain (DSP; cervical, thoracic, or lumbar sacroiliac), scored by the patient using a five-point scale ranging from 0 (no pain) to 4 (very severe pain); morning stiffness (MS) in minutes since arising; chest expansion $(\mathrm{CE})^{15}$; and lumbar flexion index (LFI), ${ }^{16}$ assessed by taking the maximum of two measurements.

Laboratory parameters included an ESR according to Westergren and serum immunoglobulins as assessed by the radial immunodiffusion method of Mancini, with standard commercially obtained immunodiffusion plates and standards (Behringer Werke, Marburg, West Germany). ${ }^{17}$ 18 All measurements were made at baseline and at weeks $12,24,36$, and 48 thereafter. In addition to the individual parameters we used an index of disease activity (IDA) to evaluate the response. The four components of this IDA and its gradings are shown in Table 1. The individual's mean of the four graded parameters was used as the IDA for that patient, being minimally 0 and maximally 4 . During the study an $x$-ray of the vertebral column, the sacroiliac joints, and the chest was made. The radiographic findings were graded according to Rogan et al. ${ }^{19}$ i.e., grade I: changes confined to sacroiliac joints; grade II: early changes in the spine and in sacroiliac joints; grade III: well marked changes in the thoracic and lumbar spine, with some evidence of ankylosis, and changes in sacroiliac joints; grade IV: gross changes in sacroiliac joints and thoracic and lumbar spine. For comparison of immunoglobulin and ESR values we used baseline data from 14 male patients with rheumatoid arthritis (RA), obtained during a single blind study comparing auranofin and aurothioglucose. ${ }^{20}$ Moreover, immunoglobulin levels of 40 healthy male blood donors, mean age 37 \pm 12 years, were used as normal controls. Their mean serum immunoglobulin concentrations plus one standard deviation were considered normal values.

The results were analysed by Student's $t$ test, always two sided and when appropriate by paired testing. Correlations were assumed to be linear, and the significance of correlation coefficients was assessed by $t$ testing.

\section{Results}

SERUM IMMUNOGLOBULIN LEVELS IN ACTIVE AS

Table 2 shows mean serum immunoglobulin levels in the active phase of AS, i.e., at baseline (week 0 ). Mean serum IgA levels were raised in both AS and RA, showing no significant difference. Serum IgM levels were higher in male patients with AS than in those with RA. In contrast, ESR values were significantly $(p<0.001)$ higher in male RA $(54 \pm 32$ $\mathrm{mm} / \mathrm{h})$ than in male AS patients $(26 \pm 18 \mathrm{~mm} / \mathrm{h})$. A study of the raised serum immunoglobulin levels showed that $\operatorname{IgA}$ was the dominantly increased

Table 1 Grading of dominant spinal pain (DSP), morning stiffness (MS), chest expansion (CE), and lumbar flexion index (LFI) according to increasing severity

\begin{tabular}{lllllll}
\hline & 0 & 1 & 2 & 3 & 4 \\
\hline DSP & $(0-4)$ & 0 & 1 & 2 & 3 & 4 \\
MS & $\min$ & $<10$ & $10-30$ & $31-60$ & $61-120$ & $>120$ \\
CE & $\mathrm{cm}$ & $\geqslant 7$ & $6 \cdot 9-5 \cdot 0$ & $4 \cdot 9-3 \cdot 5$ & $3 \cdot 4-2 \cdot 0$ & $<2 \cdot 0$ \\
LFI & $\mathrm{cm}$ & $\geqslant 7$ & $6 \cdot 9-5 \cdot 0$ & $4 \cdot 9-3 \cdot 5$ & $3 \cdot 4-2 \cdot 0$ & $<2 \cdot 0$ \\
\hline
\end{tabular}

The index of disease activity (IDA) of an individual patient is calculated as the mean of his score for the four respective components.

Table 2 Immunoglobulin levels (mean $\pm S D$ ) in healthy controls $(C)$, patients with ankylosing spondylitis (AS), and patients with rheumatoid arthritis (RA)

\begin{tabular}{|c|c|c|c|c|c|c|}
\hline & Male $C(n=40)$ & Male AS $(n=38)$ & Male $R A \quad(n=14)$ & $A S \vee C$ & $R A \vee C$ & $A S \vee R A$ \\
\hline $\operatorname{Ig} A(g / l)$ & $2 \cdot 17 \pm 0 \cdot 94$ & $3 \cdot 30 \pm 1 \cdot 53$ & $3 \cdot 73 \pm 1 \cdot 15$ & $p<0 \cdot 001$ & $\mathrm{p}<0.001$ & NS \\
\hline $\operatorname{IgM}(\mathrm{g} / \mathrm{l})$ & $1.46 \pm 0.85$ & $1 \cdot 85 \pm 0.64$ & $1.31 \pm 0.56$ & $\mathrm{p}<0.05$ & NS & $p<0.01$ \\
\hline $\operatorname{IgG}(\mathrm{g} / \mathrm{l})$ & $11 \cdot 06 \pm 2 \cdot 55$ & $14.42 \pm 3.63$ & $16 \cdot 80 \pm 5 \cdot 25$ & $\mathrm{p}<0.001$ & $p<0.001$ & $0.05<p<0.1$ \\
\hline
\end{tabular}

NS=not significant. 
serum immunoglobulin in $38 \%$ of the patients. IgG and IgM were dominantly raised in $19 \%$ and $5 \%$ of the patients with AS respectively. $38 \%$ of the patients had no serum immunoglobulin increase at all.

DISEASE ACTIVITY AND SERUM

IMMUNOGLOBULIN LEVELS

Table 3 shows correlations between serum immunoglobulin levels, ESR, and clinical parameters. Laboratory parameters frequently correlated with the objective clinical parameters, i.e., chest expansion and lumbar flexion index. Most correlations were found for $\operatorname{IgA}$ (nine times), followed by $\operatorname{IgG}$ (six times), ESR (five times), and IgM (three times). No consistent correlations were found between laboratory parameters and dominant spinal pain, morning stiffness, and the index of disease activity. Table 3 also shows a consistent and close correlation between ESR and $\operatorname{IgA}$ and, to a lesser extent, IgG.

Next we studied changes in laboratory parameters and clinical parameters during treatment. Since there were no consistent differences between the effects of both treatments, the two groups were taken together. Fig. 1 shows the mean serum immunoglobulin levels throughout the study, indicating the most significant changes in $\operatorname{IgA}$ at week 24 and thereafter. Table 4 shows correlations

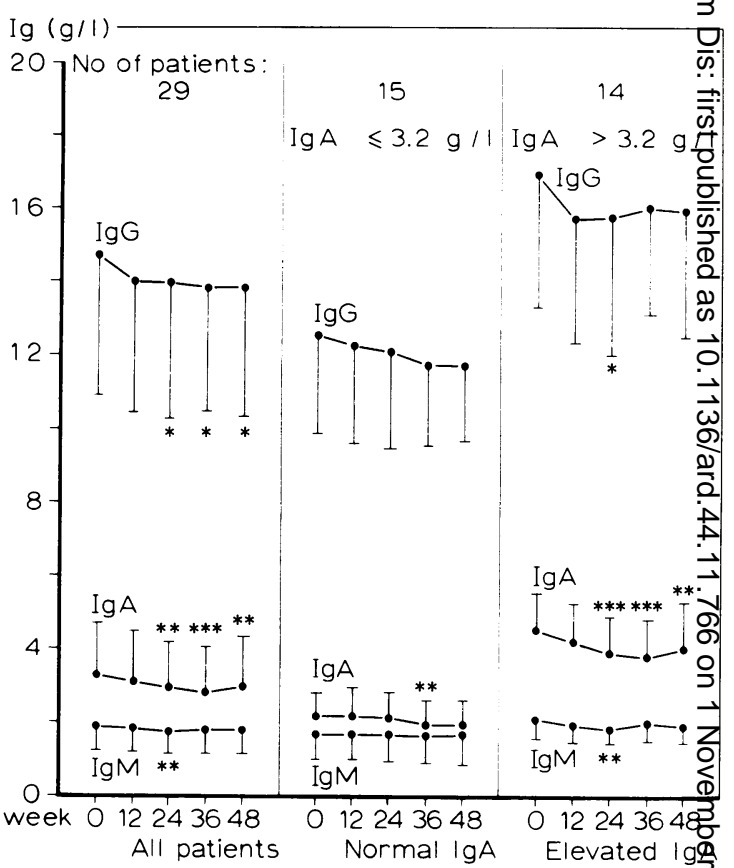

Fig. 1 Mean immunoglobulin levels during the study fo्षि $\overrightarrow{0}$ all patients completing the trial, and separately for those or with a normal and a raised $I g A$ serum level, respectivel $x$ $\left({ }^{*} p<0.05,{ }^{* *} p<0.01,{ }^{* * *} p<0.001\right)$.

Table 3 Correlations between clinical and laboratory parameters throughout the study

\begin{tabular}{|c|c|c|c|c|c|c|c|}
\hline Week & Parameter & $D S P^{*}$ & $M S$ & $C E$ & $L F I$ & $I D A$ & $E S R$ \\
\hline 0 & $\lg \mathrm{A}$ & $-0 \cdot 05$ & 0.05 & -0.28 & $-(0.47 \doteqdot$ & 0.31 & $(1.6 .58$ \\
\hline $\mathrm{n}=38$ & $\operatorname{lgM}$ & $-0 \cdot(02$ & $0.37 \div$ & $-(0) 32$ & $-(0.31$ & $0.44 \div$ & $(0 \cdot 0) 1$ \\
\hline & $\mathrm{IgG}$ & $-0 \cdot 08$ & 0.07 & $-0.33 \dagger$ & $-0.44 \div$ & 0.28 & $0.39 \div$ \\
\hline & ESR & 0.16 & $-0 \cdot 15$ & $-0 \cdot 14$ & $-(1) \cdot 43 \div$ & $0.34 \div$ & \\
\hline 12 & $\operatorname{IgA}$ & $-(0 \cdot 07$ & -0.29 & $-0.34 \div$ & $-0.53 \div$ & 0.28 & $0.50 \div$ \\
\hline$n=32$ & IgM & -0.13 & $0 \cdot 11$ & -0.24 & $-0.38 \div$ & 0.28 & $-0 .(1) 3$ \\
\hline & $\mathrm{IgG}$ & -0.31 & -0.29 & $-0 \cdot 30$ & $-0.47 \div$ & $0 \cdot(0.5$ & $(1.39 \div$ \\
\hline & ESR & $0 \cdot 26$ & $-0 \cdot 20$ & $-0 \cdot 16$ & -0.28 & 0.20 & \\
\hline 24 & $\operatorname{Ig} A$ & $-0 \cdot 02$ & 0.08 & $-0.47 \ddagger$ & $-0.61 \$$ & $0 \cdot 34$ & $(1) .70 \$$ \\
\hline \multirow[t]{3}{*}{$\mathrm{n}=29$} & IgM & 0.13 & 0.08 & -0.26 & $-0.40 \div$ & $0.40 \div$ & 0.09 \\
\hline & $\mathrm{IgG}$ & $-0 \cdot 20$ & $-0 \cdot 28$ & -0.31 & $-(0.47 \div$ & 0.08 & $0.59 \$$ \\
\hline & ESR & $-0 \cdot 01$ & -0.29 & $-0 \cdot 24$ & $-0.45 \div$ & $0 \cdot 13$ & \\
\hline \multirow[t]{3}{*}{$n=29$} & IgM & $0 \cdot 01$ & 0.02 & -0.11 & $-0.51 \ddagger$ & $0 \cdot 21$ & 0.08 \\
\hline & IgG & -0.26 & $-0 \cdot 25$ & $-0.38 \div$ & $-0.39 \div$ & $0 \cdot 06$ & $0.59 \$$ \\
\hline & ESR & $-0 \cdot 06$ & $-0 \cdot 30$ & $-0.39 \div$ & $-0.43 \div$ & $0 \cdot 15$ & \\
\hline 48 & $\operatorname{Ig} \mathrm{A}$ & $0 \cdot 15$ & $-0 \cdot 33$ & $-0.45 t$ & $-0.48 \div$ & $0 \cdot 25$ & $0.72 \$$ \\
\hline \multirow[t]{3}{*}{$n=29$} & IgM & 0.36 & -0.07 & -0.13 & -0.33 & 0.27 & 0.09 \\
\hline & IgG & $0 \cdot 10$ & -0.38 & $-0 \cdot 24$ & -0.34 & $0 \cdot 08$ & $0.63 \$$ \\
\hline & ESR & 0.08 & $-0 \cdot 21$ & -0.27 & $-0.47 \ddagger$ & $0 \cdot 20$ & \\
\hline
\end{tabular}

*Abbreviations as in Table 1.

$\dagger \mathrm{p}<0 \cdot 05$. $\ddagger \mathrm{p}<0 \cdot 01$. $\$ \mathrm{p}<0 \cdot 001$. 
Table 4 Correlations of changes as compared with baseline between parameters during the study

\begin{tabular}{|c|c|c|c|c|c|c|c|}
\hline Weeks & Parameter & $D S P^{*}$ & $M S$ & $C E$ & $L F I$ & $I D A$ & $E S R$ \\
\hline $\begin{array}{l}0-12 \\
n=32\end{array}$ & $\begin{array}{l}\text { IgA } \\
\text { IgM } \\
\text { IgG } \\
\text { ESR }\end{array}$ & $\begin{array}{l}0 \cdot 11 \\
0 \cdot 18 \\
0 \cdot 20 \\
0 \cdot 39 \ddagger\end{array}$ & $\begin{array}{l}0.25 \\
0 \cdot 28 \\
0 \cdot 17 \\
0 \cdot 23\end{array}$ & $\begin{array}{r}0 \cdot(05 \\
-0 \cdot 23 \\
-0 \cdot(03 \\
-0 \cdot 13\end{array}$ & $\begin{array}{l}-0.33 \dagger \\
-0 \cdot 43 \ddagger \\
-0 \cdot 25 \\
-0 \cdot 03\end{array}$ & $\begin{array}{l}0 \cdot 38 \ddagger \\
0 \cdot 36 \ddagger \\
0 \cdot 18 \\
0 \cdot 42 \ddagger\end{array}$ & $\begin{array}{l}0 \cdot 28 \\
0 \cdot 10 \\
0 \cdot 10\end{array}$ \\
\hline $\begin{array}{l}0-24 \\
n=29\end{array}$ & $\begin{array}{l}\operatorname{Ig} A \\
\operatorname{IgM} \\
\operatorname{IgG} \\
\text { ESR }\end{array}$ & $\begin{array}{l}0.24 \\
0 \cdot 31 \\
0 \cdot 14 \\
0 \cdot 30\end{array}$ & $\begin{array}{l}0.35 \dagger \\
0.18 \\
0 \cdot 14 \\
0.28\end{array}$ & $\begin{array}{r}0.01 \\
-0 \cdot 12 \\
-0 \cdot 14 \\
-0.03\end{array}$ & $\begin{array}{l}-0 \cdot 46 \div \\
-0 \cdot 10 \\
-0 \cdot 05 \\
-0 \cdot 16\end{array}$ & $\begin{array}{l}0 \cdot 54 \$ \\
0 \cdot 37 \ddagger \\
0 \cdot 28 \\
0 \cdot 56 \$\end{array}$ & $\begin{array}{l}0 \cdot 13 \\
0 \cdot 06 \\
0.09\end{array}$ \\
\hline $\begin{array}{l}0-36 \\
n=29\end{array}$ & $\begin{array}{l}\text { IgA } \\
\text { IgM } \\
\text { IgG } \\
\text { ESR }\end{array}$ & $\begin{array}{l}0.29 \\
0 .(15 \\
0 \cdot 17 \\
0.39 \ddagger\end{array}$ & $\begin{array}{l}0 \cdot 32 \dagger \\
0 \cdot 00 \\
0 \cdot 21 \\
0 \cdot 20\end{array}$ & $\begin{array}{r}0 \cdot 00 \\
0 \cdot 22 \\
0 \cdot 06 \\
-0 \cdot 07\end{array}$ & $\begin{array}{c}-0 \cdot 37 \ddagger \\
-0.08 \\
0 \cdot 01 \\
-0 \cdot 15\end{array}$ & $\begin{array}{c}0.41 \ddagger \\
-0 \cdot 12 \\
0.06 \\
0 \cdot 39 \ddagger\end{array}$ & $\begin{array}{l}0.45 \ddagger \\
0 \cdot 16 \\
0.07\end{array}$ \\
\hline $\begin{array}{l}0-48 \\
n=29\end{array}$ & $\begin{array}{l}\operatorname{IgA} \\
\operatorname{IgM} \\
\operatorname{IgG} \\
\text { ESR }\end{array}$ & $\begin{array}{r}-0 \cdot(03 \\
0 \cdot 06 \\
0 \cdot(12 \\
0 \cdot(07\end{array}$ & $\begin{array}{r}0 \cdot 12 \\
-0 \cdot 14 \\
0 \cdot 13 \\
0 \cdot 05\end{array}$ & $\begin{array}{r}-0 \cdot 11 \\
-0 \cdot 09 \\
-0 \cdot 07 \\
0 \cdot(22\end{array}$ & $\begin{array}{l}-0.33+ \\
-0.28 \\
-0.12 \\
-0.05\end{array}$ & $\begin{array}{l}0 \cdot 34 \dagger \\
0 \cdot 14 \\
0 \cdot 29 \\
0 \cdot 17\end{array}$ & $\begin{array}{l}0.58 \S \\
0.04 \\
0.02\end{array}$ \\
\hline
\end{tabular}

${ }^{*}$ Abbreviations as in Table 1 .

$+0 \cdot 05<\mathrm{p}<0 \cdot 1$. $\$ \mathrm{p}<0 \cdot 05$. $\$ \mathrm{p}<0 \cdot 01$.

$\operatorname{Ig} A(g / 1)$

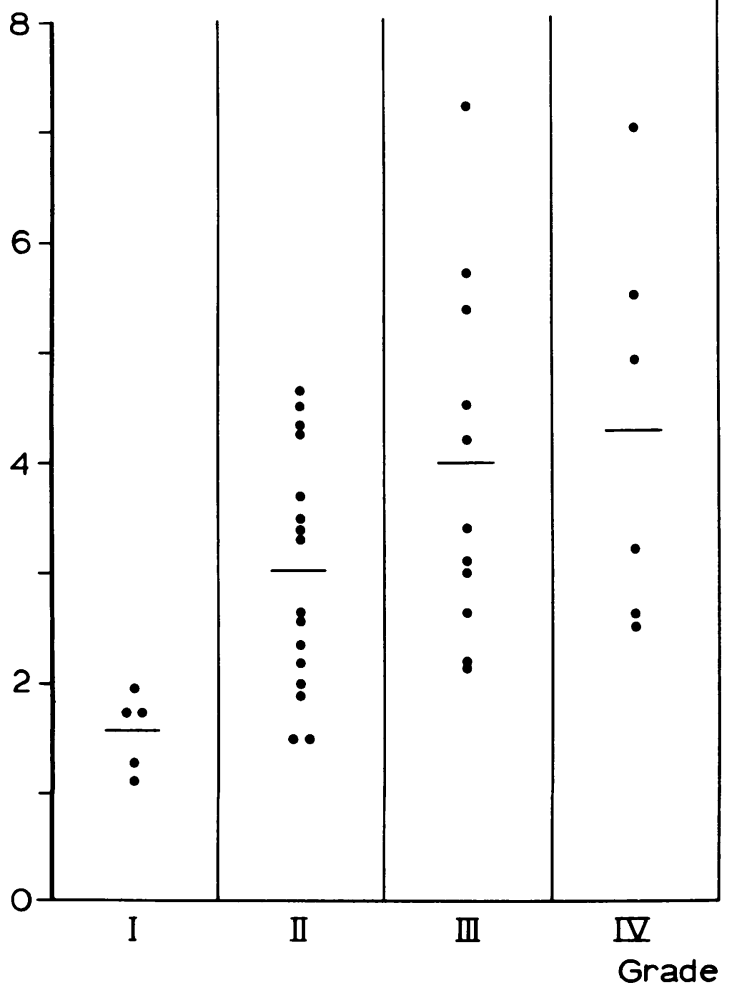

Fig. 2 Radiological gradings of the axial skeleton ${ }^{19}$ and serum IgA levels at baseline. between changes during treatment. This table indicates that, so far as immunoglobulins and index of disease activity are concerned, most correlations are found for $\operatorname{IgA}$, followed by $\operatorname{IgM}$. Correlations of ESR with index of disease activity were comparable with those of $\operatorname{IgA}$, though correlations between $\operatorname{IgA}$ and ESR became significant only after 36 and 48 weeks. Of the individual IDA components only lumbar flexion index changes showed correlations with immunoglobulin changes, most frequently with IgA: twice significant and twice close to significance $(0 \cdot 05<\mathrm{p}<0 \cdot 1)$.

RELATION BETWEEN SERUM IgA LEVELS AT BASELINE AND RADIOLOGICAL FEATURES Since radiological features at least partly reflect disease activity, we studied serum immunoglobulin levels in the various radiological categories. As shown in Fig. 2 radiological grades II, III, and IV differ significantly from grade $I$ in mean serum IgA level $(p<0 \cdot 01)$. No such differences were found for IgM and IgG.

\section{Discussion}

This study presents evidence that serum IgA levels, more than those of IgM and IgG, are associated with disease activity in ankylosing spondylitis. Firstly, absolute values of serum $\operatorname{IgA}$ were found to correlate with the objective disease parameters lumbar flexion index and chest expansion throughout the study. Secondly, and probably most important, changes in serum $\operatorname{IgA}$ correlated with changes of 
disease activity expressed as an index of disease activity (IDA). Finally, mean serum IgA levels increased as the radiological changes became more severe. It should be stressed that these data apply only to the group studied, i.e., male patients with ankylosing spondylitis without peripheral arthritis who showed a flare up of pain and stiffness after a drug-free period.

Serum immunoglobulin levels have been found to be raised in ankylosing spondylitis by several authors, the most significant rise being that of serum $\operatorname{IgA} .^{1-4} \mathrm{~A}$ few studies have indicated that serum $\operatorname{IgA}$ levels may be related to disease activity. ${ }^{2} 31213$ However, no longitudinal studies have previously been done. The present study is the first to show that changes in serum $\operatorname{IgA}$ levels parallel changes in disease activity of ankylosing spondylitis. Similar changes were not found for the other immunoglobulins studied.

Evidence that serum $\operatorname{IgA}$ levels are somehow related to disease activity in ankylosing spondylitis may be important in several respects. A number of studies have indicated that other HLA-B27 related disorders, e.g., Reiter's syndrome and reactive arthritis, can be precipitated by an enteric infection. ${ }^{21-23}$ Since $\operatorname{Ig} \mathrm{A}$ is the predominant immunoglobulin produced by the gastrointestinal mucosa, ${ }^{11}$ association of IgA serum levels and disease activity as found in the present study may point to the localisation of a causative pathogen in the gut. ${ }^{267}$ In fact Ebringer et al. ${ }^{5}$ have reported evidence of the association between the presence of Klebsiella pneumoniae in the faeces of patients with ankylosing spondylitis and active disease. Other groups, however, have been unable to confirm these data. ${ }^{8-10}$ Another interesting observation was that serum IgA levels decreased during regular treatment with NSAIDs. Since changes in serum IgA were paralleled by changes in disease activity, these observations suggest that NSAIDs may have a disease modifying effect in ankylosing spondylitis. The observation in our study that there was also a decrease in ESR during treatment is compatible with this view. In this respect it is interesting that one previous study presents evidence of delayed ossification of the lumbar vertebral column in ankylosing spondylitis due to phenylbutazone treatment. ${ }^{24}$

It is of practical importance that the present data justify the use of serum $\operatorname{IgA}$ levels as another parameter of disease activity. At present ESR and acute phase proteins such as C-reactive protein (CRP) are most frequently used as laboratory parameters of disease activity. ${ }^{25}$ However, the value of the latter parameters has been questioned in AS. ${ }^{326}$ In any case the serum IgA levels may give valuable additional information, as suggestec by our finding that especially in the earlier part of the trial there was no correlation between changes in ESR and those in IgA serum levels. In our group of? patients the mean serum $\operatorname{IgA}$ levels were related tog the extent of radiological abnormalities. The latte at least partly reflects disease severity, though? duration of the disease admittedly also plays a part $\stackrel{D}{\varrho}$ If as suggested by our data serum IgA levels reflectes disease activity, this would mean that patients withpersistently raised serum IgA levels are most at risk of developing extensive axial inflammation anct therefore ankylosis and flexion deformity. This group should be considered for regular treatmen $\bar{\sigma}$ with NSAIDs, especially when this type of treat $A$ ment has a disease modifying effect as our data suggest.

\section{References}

1 Kinsella T D, Espinoza L. Vasey F B. Scrum complement and immunoglobulin levels in sporadic and familial ankylosing $Z$ spondylitis. J Rheumatol 1975; 2: 308-13.

2 Cowling P, Ebringer R, Ebringer A. Association of inflammation with raised serum $\lg \mathrm{A}$ in ankylosing spondylitis. $A n r$ Rheum Dis 1980; 39: 545-9.

3 Laurent M R. Panayi G S. Acute-phase proteins and seram immunoglobulins in ankylosing spondylitis. Ann Rheum $\mathrm{Q}_{i} \mathrm{~s}$ 1983; 42: $524-8$

4 Vinje O, Möller P. Mellbye J. Immunological variables acute-phase reactants in patients with ankylosing spondy and their relatives. Clin Rheumatol 1984; 3: 501-14.

5 Ebringer R W, Cawdell D R, Cowling P, Ebringer A. Sequential studies in ankylosing spondylitis-association of Klebsiella pneumoniae with active disease. Ann Rheum Dis $\frac{\mathrm{Q}}{\mathbb{Q}}$ 1978; 37: 146-51.

6 Trull A K. Panayi G S. Serum and secretory IgA immunc $\overrightarrow{\bar{D}}$ response to Klebsiella pneumoniae in ankylosing spondylitis. Clin Rheumatol 1983; 2: 331-7.

7 Calguneri M, Swinburne L, Shinebaum R, Cooke E M, Wright V. Secretory IgA: immune defence pattern in ankylosing. spondylitis and klebsiella. Ann Rheum Dis 1981; 40: 600)-4.

8 Warren R E, Brewerton D A. Faecal carriage of klcbsiclla by patients with ankylosing spondylitis and rheumatoid arthritis. Ann Rheum Dis 1980; 39: 37-44.

9 Eastmond C J, Willshaw H E, Burgess S E P, Shinebaum R Cooke E M, Wright V. Frequency of faccal Klebsiella aerogenes in patients with ankylosing spondylitis and controls with respeck to individual features of the disease. Ann Rheum Dis 1980; 39윽

10 Shinebaum R, Neumann V, Hopkins R, Cooke E M, Wright V $D$ Attempt to modify klebsiella carriage in ankylosing spondylitis patients by diet: correlation of klebsiella carriage with disease activity. Ann Rheum Dis 1984; 43: 196-9.

11 Tomasi T B. Secretory immunoglobulins. N Engl J Med 1972; 287: 500-6.

12 Hickling P, Turnbull L, Dixon J S. The relationship betweenc disease activity, immunoglobulins and lymphocyte subpopula- $\sigma$ tions in ankylosing spondylitis. Rheumatol Rehabil 1982; 21: $145-50$.

13 Trull A K, Ebringer R W, Panayi G S, Colthorpe D, James D C $\mathrm{O}$, Ebringer A. IgA antibodies to Klebsiella pneumoniae in? ankylosing spondylitis. Scand $J$ Rheumatol 1983; 12: 249-53.

14 Bennett P H I, Burch T A. Population studies of the rheumatic diseases. Amsterdam: Excerpta Medica, 1968; 456-7. 
15 Moll J M H. Wright V. An objective clinical study of chest expansion. Ann Rheum Dis 1972; 31: 1-8.

16 Adrichem van J A M. Korst van der J K. Assessment of the flexibility of the lumbar spine. Scand J Rheumatol 1973; 2: 87-91.

17 Mancini G. Carbonara H O. Heremans J F. Immunological quantification of antigens by single radial immunodiffusion. Immunochemistry 1965: 2: 235-54.

18 Riel van P L C M. Putte van de L B A. Gribnau F W J. Waal de $\mathrm{R} M \mathrm{M}$. Serum IgA and gold-induced toxic effects in patients with rheumatoid arthritis. Arch Intern Med 1984: 144: 1401-3.

19 Rogan M C. Needham C D. McDonald I. Effect of ankylosing spondylitis on ventilatory function. Clin Sci 1955; 14: 91-6.

20 Riel van P L C M. Putte van de L B A. Gribnau F W J. Macrae $K$ D. Comparison of auranofin and aurothioglucose in the treatment of rhcumatoid arthritis: a single blind study. Clin Rheumatol 1984; 3 (suppl 1): 51-6.

21 Ahvonen P. Sievers K. Aho U. Arthritis associated with
Yersinia enterocolitica. Acta Rheumatol Scand 1969; 15: 232-53.

22 Warren C P W. Arthritis associated with salmonella infections. Ann Rheum Dis 1970; 29: 483-7.

23 Putte van de L B A. Berden J H M. Bocrbooms A M T. et al. Reactive arthritis after Campylobacter jejuni enteritis. J Rheumatol 1980: 7: 531-5.

24 Boersma J W. Retardation of ossification of the lumbar vertebral column in ankylosing spondylitis by means of phenylbutazone. Scand J Rheumatol 1976: 5: 60-4.

25 Cowling P. Ebringer R, Cawdell D. Ishii M, Ebringer A, C-reactive protein. ESR, and klebsiclla in ankylosing spondylitis. Ann Rheum Dis 1980: 39: 45-9.

26 Kendall M J. Lawrence D S. Shuttleworth G R. Whitficld A G W. Haematology and biochemistry of ankylosing spondylitis. Br Med J 1973: ii: 235-7.

27 Scott D G I, Ring E F J. Bacon P A. Problems in the assessment of disease activity in ankylosing spondylitis. Rheumatol Rehabil 1981; 20: 74-80.

\section{Book review}

Research. How to Plan, Speak and Write About It. Eds. Clifford Hawkins and Marco Sorgi. Pp. 184. £8.75. Springer: Berlin. 1985.

This book encapsulates in one volume the various aspects of research involvement and is particularly concerned with presenting its results. Of the eight chapters, the editors have contributed to three. The contents include chapters on: Research: why do it?; Planning and protocol; Searching the literature; Speaking at meetings; What the critical reader looks for in an original article; A guide for writers; Illustrating talks or articles; A guide to statistical methods; Publication. In addition, the work is most usefully supplemented by a series of appendices, including notes on the MD thesis, advice on using a dictating machine, and lists of needless and verbose words. There are also appendices on American and British usage in spelling, abbreviations of journal titles, and guidelines for putting up poster displays.

The book is intended to be an aid for anyone starting out in research or someone who is already undertaking it. The intention of the editors is fully met by this work, which will provide embryo or established researchers with a wealth of useful information.

The coverage offers a good balance between verbal and visual aspects of communication, and throughout the reader is given the benefit of much practical experience from the editors and contributors. This is, therefore, a theory-and-practice approach, making the volume all the more valuable.

Anyone writing in this field to some extent exposes their style of presentation to scrutiny more than usual. However, these authors have strongly upheld the "practice what is preached' philosophy, and the book throughout is clearly and pleasingly written. It is sirongly recommended.

Consultant Physician in Rheumatology,

J M H MOLL

Nether Edye Hospital,

Sheffield 